\title{
Thermal performance of sisal fiber-cement roofing tiles for rural constructions
}

\author{
Gustavo Henrique Denzin Tonoli'; Sérgio Francisco dos Santos²; José Antonio Rabi²; \\ Wilson Nunes dos Santos ${ }^{3}$; Holmer Savastano Junior ${ }^{2 *}$ \\ ${ }^{1}$ USP/FZEA - Programa de Pós-graduação em Zootecnia, Av. Duque de Caxias Norte, 225 - $13635-900$ - \\ Pirassununga, SP - Brasil. \\ ${ }^{2}$ USP/FZEA - Depto. de Engenharia de Alimentos. \\ ${ }^{3}$ UFSCAR - Depto. de Engenharia de Materiais, Via Washington Luiz, km 235, C.P. 676 - $13565-905$ - São \\ Carlos, SP - Brasil. \\ *Corresponding author < holmersj@usp.br>
}

\begin{abstract}
Roofing provides the main protection against direct solar radiation in animal housing. Appropriate thermal properties of roofing materials tend to improve the thermal comfort in the inner ambient. Nonasbestos fiber-cement roofing components reinforced with cellulose pulp from sisal (Agave sisalana) were produced by slurry and dewatering techniques, with an optional addition of polypropylene fibers. Nonasbestos tiles were evaluated and compared with commercially available asbestos-cement sheets and ceramic tiles (frequently chosen as roofing materials for animal housing). Thermal conductivity and thermal diffusivity of tiles were determined by the parallel hot-wire method, along with the evaluation of the downside surface temperature. Cement-based components reinforced with sisal pulp presented better thermal performance at room temperature $\left(25^{\circ} \mathrm{C}\right)$, while those reinforced with sisal pulp added by polypropylene fibers presented better thermal performance at $60^{\circ} \mathrm{C}$. Non-asbestos cement tiles provided more efficient protection against radiation than asbestos corrugated sheets.

Key words: cellulose pulp, polypropylene fiber, thermal comfort, parallel hot-wire method, thermal conductivity
\end{abstract}

\section{Desempenho térmico de telhas de fibrocimento reforçadas com polpa de sisal para construções rurais}

\begin{abstract}
RESUMO: O telhado fornece a principal proteção contra a radiação solar direta em galpões para animais. Propriedades térmicas apropriadas dos materiais contribuem para o melhor conforto térmico no interior das construções. Telhas sem amianto reforçadas com polpa de celulose de sisal (Agave sisalana) e com adição opcional de fibras de polipropileno foram produzidas pela técnica de mistura e sucção do excesso de água. Telhas corrugadas de cimento amianto, telhas cerâmicas e telhas à base de cimento reforçadas com polpa de celulose (com ou sem adição de fibras sintéticas) foram comparadas quanto às suas propriedades térmicas. A condutividade térmica e a difusividade térmica foram determinadas pelo método do fio quente paralelo, assim como a temperatura da superfície inferior das telhas foi avaliada em diferentes períodos. Telhas de cimento reforçados com polpa de sisal apresentaram as melhores propriedades térmicas em temperatura ambiente $\left(25^{\circ} \mathrm{C}\right)$, enquanto aquelas reforçadas com polpa de sisal associada a fibras de polipropileno apresentaram melhor desempenho térmico a $60^{\circ} \mathrm{C}$. As telhas sem amianto forneceram proteção mais eficiente contra a radiação térmica do que as telhas corrugadas de amianto.

Palavras-chave: polpa de celulose, fibras de polipropileno, conforto térmico, método do fio quente paralelo, condutividade térmica
\end{abstract}

\section{Introduction}

Despite the concerns about the asbestos banishment, asbestos-cement corrugated sheets are claimed as the cheapest alternative for roofing in Brazil (Conceição et al., 2008). Thermal insulation provided by this material has been considered worse than that by ceramic tiles. Studies on thermal comfort rendered by roofing tiles reinforced with vegetable fibers were carried out by Kawabata et al. (2005) and Roma Jr. et al. (2008). Vegetable fibers added to cement roofing tiles enhance the thermal insulation in comparison to asbestos-cement tiles, specially due to their higher porosity and to air incorporation into the composite (Roma Jr. et al., 2008).

Roofing is the building component that contributes most to the indoor environment and to the corresponding thermal comfort assessment with regard to animal housing (Conceição et al., 2008). To keep their homeothermy, animals rely on thermoregulatory mechanisms that may lead to physiological compensations in detriment of production (Grant and Albright, 1995). When no metabolic energy is spent to compensate either cold or heat stresses, animals are expected to be in comfort conditions and, consequently, to achieve maximum productivity. As far as human thermal comfort is concerned, a similar motivation has been attempted in 
terms of exergy loss and/or entropy generation (Boregowda et al., 2001; Prek, 2004, 2006).

An economic way to help animals to keep their (energetic) homeostasis is to control the thermal radiation transferred to the indoor ambient. Therefore, bearing in mind animal housing, thermal properties of roofing materials must be evaluated in view of their direct influence on indoor thermal comfort. Use of materials with suitable thermal properties may allow one to set better environmental conditions inside the building. The present research aimed at evaluating thermal parameters (e.g. thermal conductivity and heat transfer rate) of vegetable fiber-cement roofing tiles as well as at comparing these tiles to existing commercial options (ceramic and asbestos-cement) in terms of thermal performance.

\section{Material and Methods}

Cement-based roofing tiles reinforced with cellulose pulp are non-combustible and impermeable when exposed to rainfall. Based on a prior study (Tonoli et al., 2007), materials and formulations used in their production are described in Table 1 . Refined conventional Kraft sisal pulp (Figure 1) was previously dispersed in water by mechanical stirring at $1,700 \mathrm{rpm}$ during $30 \mathrm{~min}$. Polypropylene fibers were then added and stirring was resumed for additional $20 \mathrm{~min}$.

The mixture was made with approximately $40 \%$ of solids. Figure 2 depicts some steps during the tile prepa-

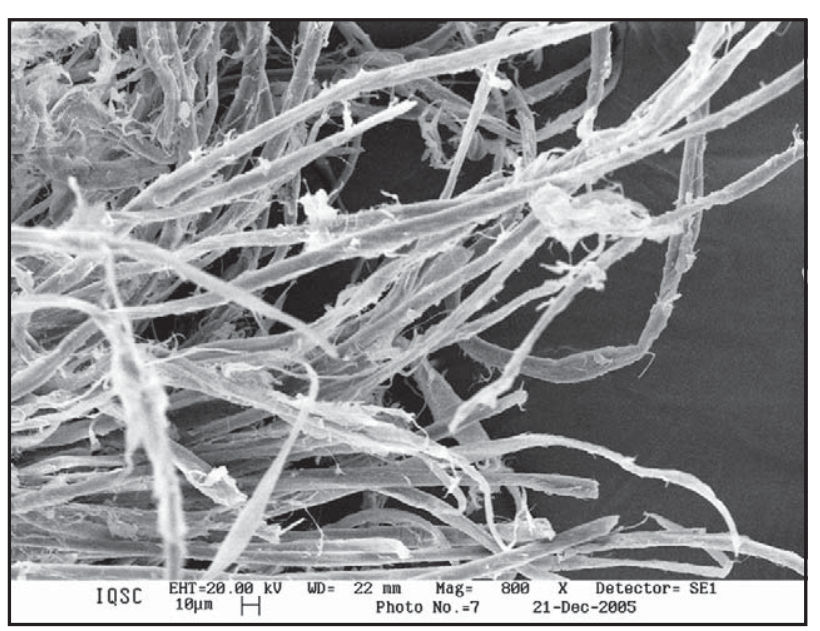

Figure 1 - Scanning electron microscopy (SEM) micrograph of the refined sisal pulp fibers. ration sequence using an automated device (Tonoli et al., 2010). The slurry mixture was transferred to a storage container located in the upper part of the equipment (Figure 2a). Driven by an automated system, this container can slide along the horizontal direction so as to transfer the mixture to a molding chamber whose approximate dimensions are $500 \mathrm{~mm}$ (long), $275 \mathrm{~mm}$ (wide) and $8 \mathrm{~mm}$ (thick). The undulate tile was formed and pressed by pneumatic pistons in the upper surface while the dewatering system was applied in the down side during $30 \mathrm{~s}$ to drain excess water (Figure 2a). Afterwards, negative pressure was applied to the upper device (Figure 2b) for additional $30 \mathrm{~s}$ and finally the conformed tile was transferred from the molding chamber to an undulate mold in order to render its final shape (Figures 2c and 2d).

The initial cure was carried out at room condition (namely, $25 \pm 2{ }^{\circ} \mathrm{C}, 70 \pm 5 \%$ relative humidity). Covered with plastic bags, roofing tiles remained within the molds for two days. After this period, roofing tiles were removed from molds and immersed in cement-saturated water for subsequent 26 days. Non-asbestos tiles $(8 \mathrm{~mm}$ thick) produced in the present work were compared with commercially available asbestos-cement sheets (4 $\mathrm{mm}$ thick) and red ceramic tiles (12 $\mathrm{mm}$ thick), which are a frequent roofing choice for animal housing.

Values for water absorption (WA), apparent void volume (AVV) and bulk density (BD) of the roofing tiles were obtained after ten replicates of each formulation, following procedures specified by the ASTM C 948-81 (1981) Standard.

The parallel hot wire method (ISO 8894-2, 1990) was applied in order to determine the thermal conductivity of fiber-cement composites. The parallel hot-wire technique was chosen based on the following line of reasoning (Santos, 2008): (i) it requires prismatic specimens with representative dimensions (i.e., considerably large dimensions); (ii) it enables one to measure thermal conductivities at room temperature (which is impossible via calorimetric methods); and (iii) the temperature gradient across the sample can be quite low (thermal conductivity should be ideally measured over a zero temperature gradient across the sample).

Prismatic specimens with dimensions around $230 \times$ $112 \times 59 \mathrm{~mm}^{3}$ were produced for each formulation listed in Table 1. One batch with asbestos-cement was produced via Hatschek process following a commercial formulation (\% by mass), namely: $10.0 \%$ of asbestos fiber,

Table 1 - Mix-design for the production of undulate non-asbestos roofing tiles.

\begin{tabular}{|c|c|c|}
\hline Raw material & S1 & S2 \\
\hline & \multicolumn{2}{|c|}{ \% by mass, dry basi- } \\
\hline Refined sisal Kraft pulp & 4.7 & 3.0 \\
\hline Polypropylene fiber (PP) & 0.0 & 1.7 \\
\hline Ordinary Portland Cement (CP V-ARI) ${ }^{a}$ & 78.8 & 78.8 \\
\hline Ground carbonate material & 16.5 & 16.5 \\
\hline
\end{tabular}

${ }^{a}$ ABNT (1983) clinker + gypsum $=100-95 \%$; carbonate material $=0-5 \%$ by mass. 
$1.7 \%$ of cellulose pulp, $71.3 \%$ of ordinary Portland cement (CP V-ARI, NBR 5733-1983) and $17.0 \%$ of ground carbonate material. Asbestos-cement was used in order to determine the thermal conductivity of the commercial roofing sheets (widely used in developing countries like Brazil). For the thermal conductivity of ceramic tiles, the value reported in the literature (Padilha et al., 2001) was adopted.
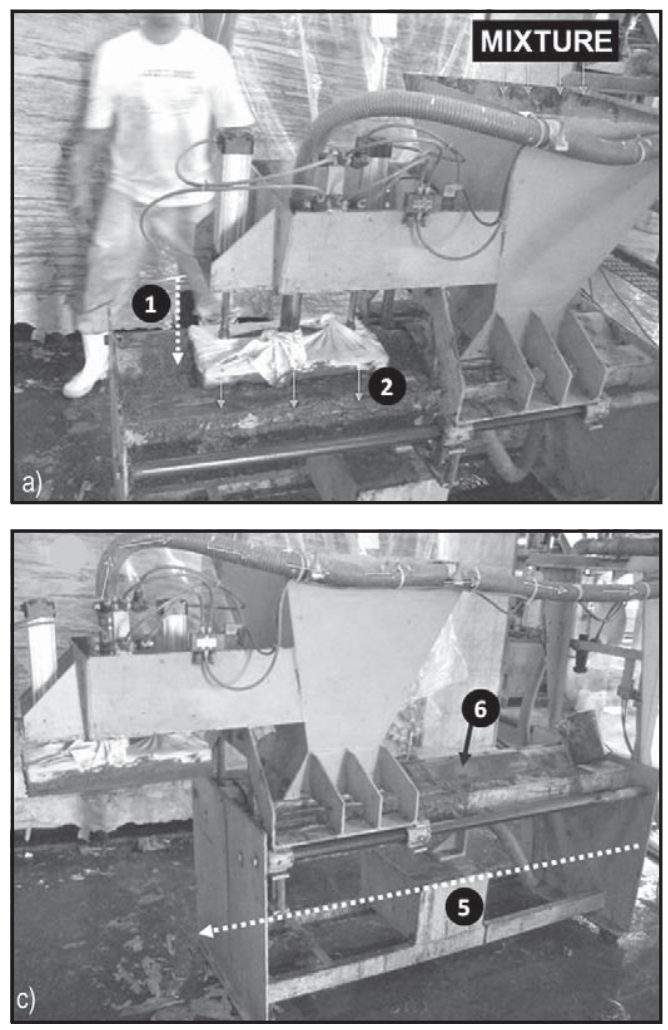

After a curing period of 28 days, the parallelepiped samples were dried and then tested (40 days later) at room conditions, i.e., $25 \pm 2{ }^{\circ} \mathrm{C}, 70 \pm 5 \%$ relative humidity. Figure 3 shows the arrangement of the prismatic specimens for the thermal conductivity analysis. Detailed procedures concerning the arrangement of specimens for the parallel hot-wire technique are described by Santos (2002).
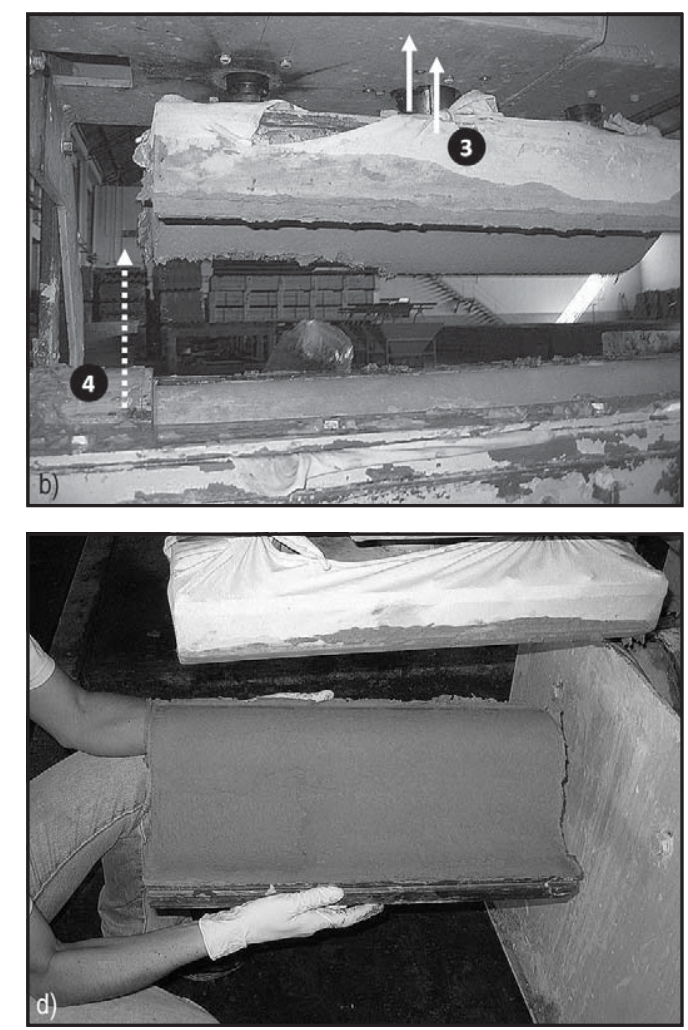

Figure 2 - Steps sequence of the automated device used for roofing tile molding: (a) pressing in the molding chamber (arrow 1) and dewatering (arrow 2); (b) suction by the upper device (arrow 3) and withdrawal from the molding chamber (arrow 4); (c) displacement of the upper device (arrow 5) and further filling the molding chamber with the mixture (arrow 6); (d) transfer of the tile to the undulate mold.
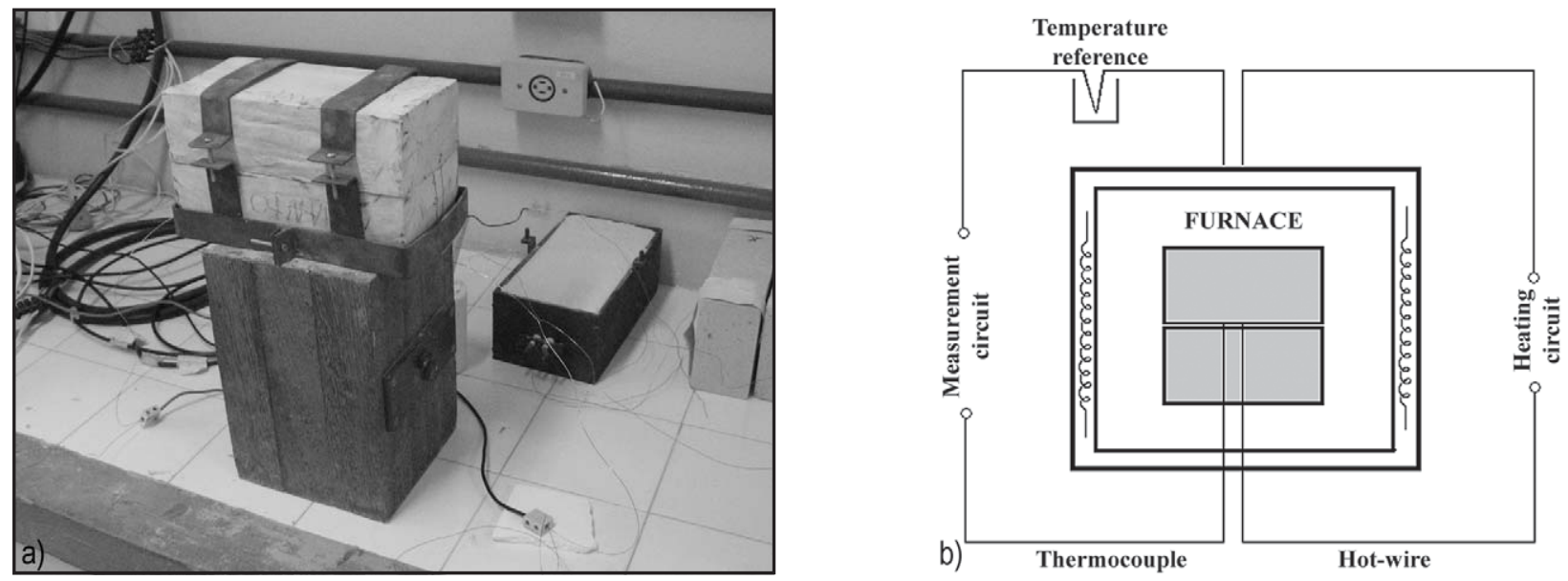

Figure 3 - (a) Specimen arrangement for parallel hot-wire analysis. (b) Frontal sketch of the hot wire apparatus and the specimen arrangement inside the furnace (not to scale). 
Measurements were carried out at room temperature $\left(\sim 25^{\circ} \mathrm{C}\right)$ and at a higher one (namely, $\left.60^{\circ} \mathrm{C}\right)$, chosen as an attempt to simulate the condition under which roofing tiles are normally exposed during the hottest period of the day in tropical regions. Once thermal equilibrium has been reached (after a stabilization period of $8 \mathrm{~h}$, at least), the hot-wire circuit was closed and the thermal transient was recorded at a measuring point at a known distance $d(=16 \mathrm{~mm})$ from the hot wire. Minimum and maximum time lags employed in calculations were chosen according to the simulation model proposed by Santos (2003).

Applying a constant electric current across the wire and recording the temperature rise $T(t)[\mathrm{K}]$ at the measuring point (with respect to the initial reference temperature), where $t[s]$ is the elapsed time after the beginning of the heat release, the thermal conductivity $k$ [W $\left.(\mathrm{m} \times \mathrm{K})^{-1}\right]$ of the material is calculated according to the following expression:

$$
k=-\frac{q^{\prime}}{4 \pi T(t)} E_{i} \quad, \quad E_{i}=E_{i}\left(-\frac{\rho c d^{2}}{4 k t}\right)
$$

where other material properties include bulk density $\rho\left[\mathrm{kg} \mathrm{m}^{-3}\right]$ and specific heat capacity $c\left[\mathrm{~J}(\mathrm{~kg} \mathrm{~K})^{-1}\right], q^{\prime}[\mathrm{W}$ $\left.\mathrm{m}^{-1}\right]$ is the linear power density, $d[\mathrm{~m}]$ is the distance between the hot wire and the thermocouple (used to register the temperature rise), and $-E_{i}(-x)$ is the (dimensionless) exponential integral function given by:

$-E_{i}(-x)=\int_{x}^{\infty} \frac{e^{-t}}{t} d t$

Introducing the so-called Euler constant $\gamma=$ 0.5772156649 , the previous function can be expanded as the following power series:

$$
-\operatorname{Ei}(-x)=\operatorname{E1}(x)=-\gamma-\ln x-\sum_{n=1}^{\infty} \frac{(-1)^{n} x^{n}}{n n !}
$$

provided that $|\arg x|<\pi$, where $\arg x=\tan ^{-1}\left(x_{2} / x_{1}\right)$ and $x=x_{1}+i \times x_{2}\left(i^{2}=-1\right)$.

Starting from the recorded temperature transient, calculations are carried out relying on a non-linear leastsquares fitting method. Values for the thermal conductivity $k$ and for the specific heat capacity $c$ are fitted aiming at a compromise between the transient temperature profile experimentally registered and the one predicted on theoretical basis, i.e., by the model equation, Eq. 1. In the present case, these two thermal properties ( $k$ and $c)$ are simultaneously fitted based on the same experimental data. Accordingly, provided that the density $r$ is known, the thermal diffusivity $\alpha\left[\mathrm{m}^{2} \mathrm{~s}^{-1}\right]$ is calculated from Eq. 4:

$\alpha=\frac{\mathrm{k}}{\rho \mathrm{c}}$

Measurements were accomplished during approximately one summer month in a rural area of Pirassununga, state of São Paulo, Brazil (2159' S; 47²5' $\mathrm{W}$ and mean elevation of around $630 \mathrm{~m}$ ). During the pe- riod under consideration, maximum and minimum temperatures were respectively $32.7^{\circ} \mathrm{C}$ and $13.8^{\circ} \mathrm{C}$, average and maximum wind speeds were respectively $3.0 \mathrm{~m} \mathrm{~s}^{-1}$ and $15.5 \mathrm{~m} \mathrm{~s}^{-1}$, rainfall was approximately $145 \mathrm{~mm}$, average relative humidity was $75.4 \%$, and maximum solar radiation was $1289 \mathrm{~W} \mathrm{~m}^{-2}$. These parameters are required to compare the temperatures of the downside surface of the non-asbestos roofing tiles (sisal fiber-cement and sisal + PP fiber-cement) in relation to the ceramic tiles and asbestos-cement corrugated sheets commercially available in the Brazilian market.

The three roofing systems were positioned onto a metallic structure facing north with $30^{\circ}$ of inclination in relation to the horizontal plane (Figure 4). Sensors (TMC1-HA cable) were placed under the roofing tiles to register the downside surface temperature. Protected by an expanded polystyrene layer to avoid the influence from the surrounding temperature, these sensors were connected to data-loggers (ONSET $\mathrm{HOBO}^{\circledR} \mathrm{H} 8$ ) with a temperature range from $-40^{\circ} \mathrm{C}$ to $+100^{\circ} \mathrm{C}$ and accuracy of $\pm 0.5^{\circ} \mathrm{C}$. Temperatures were recorded at every 15 min, and profiles were extracted from data-loggers via BoxCar Pro 4.3 software.

Normalization was used to analyze the thermal performance of the roofing elements with respect to the thermal conductivity $k$, the projected area $A\left[\mathrm{~m}^{2}\right]$ and the thickness $e[\mathrm{~m}]$ of the tile, in conjunction with the temperature gradient $T_{2}-T_{1}$, where $T_{2}[\mathrm{~K}]$ is the outside temperature and $T_{1}[\mathrm{~K}]$ is the temperature at the downside surface of the tile. Absolute values of heat transfer rates $\mathrm{dQ} / \mathrm{d} t[\mathrm{~W}]$ across the tile were assessed by Eq. 5:

$$
\frac{\mathrm{dQ}}{\mathrm{dt}}=\left|\mathrm{kA} \frac{\mathrm{T}_{2}-\mathrm{T}_{1}}{\mathrm{e}}\right| \Rightarrow \frac{\mathrm{dQ}}{\mathrm{dt}}=\mathrm{kA} \frac{\left|\mathrm{T}_{2}-\mathrm{T}_{1}\right|}{\mathrm{e}}
$$

To compare the thermal performance of distinct roofing elements, the upside surface temperature was not measured so that $T_{2}$ was assigned as the temperature of the outside air. Such initial comparison may then be subjected to adjustments as, for example, differences in tile colors. In addition, the initial color may change with age and/or usage time due to dirt deposition and microbial growth on the surface. In view of that, only new tiles were used in the present work.

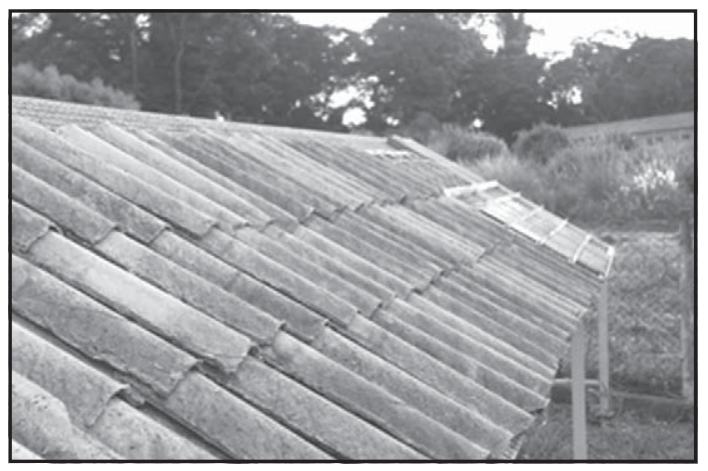

Figure 4 - Metallic structure for weather exposition of roofing elements. 


\section{Results and Discussion}

Sisal and sisal + PP fiber-cement (here identified as S1 and S2, respectively) presented higher WA and AVV than asbestos-cement and ceramic (Figure 5a) due to the air trapped by sisal pulp and/or PP fibers (for S2). S1 and $\mathrm{S} 2$ and fiber-cement tiles presented lower BD than asbestos-cement and ceramic tiles (Figure $5 \mathrm{~b}$ ).

Transient temperature profiles registered for the asbestos-cement tiles and for the non-asbestos ones $\mathrm{S} 1$ and $\mathrm{S} 2$ at $25^{\circ} \mathrm{C}$ and $60^{\circ} \mathrm{C}$ are shown in Figures 6 and 7, respectively. If particularly compared to non-asbestos tiles S2, higher temperature levels are observed for the asbestos-cement tiles. Thermal conductivity and specific heat capacity were obtained from Eq. 1 while, using the proper thermal properties, thermal diffusivity was assessed from Eq. 4. Values obtained for thermal conductivity were similar to those indicated by Padilha et al. (2001) for fiber-cement-based products.

Figure 8 presents the values for thermal conductivity $k$, specific heat capacity $c$ and thermal diffusivity $\alpha$ obtained via parallel hot-wire method for the composites at room temperature $\left(\sim 25^{\circ} \mathrm{C}\right)$ and at $60^{\circ} \mathrm{C}$. Com-
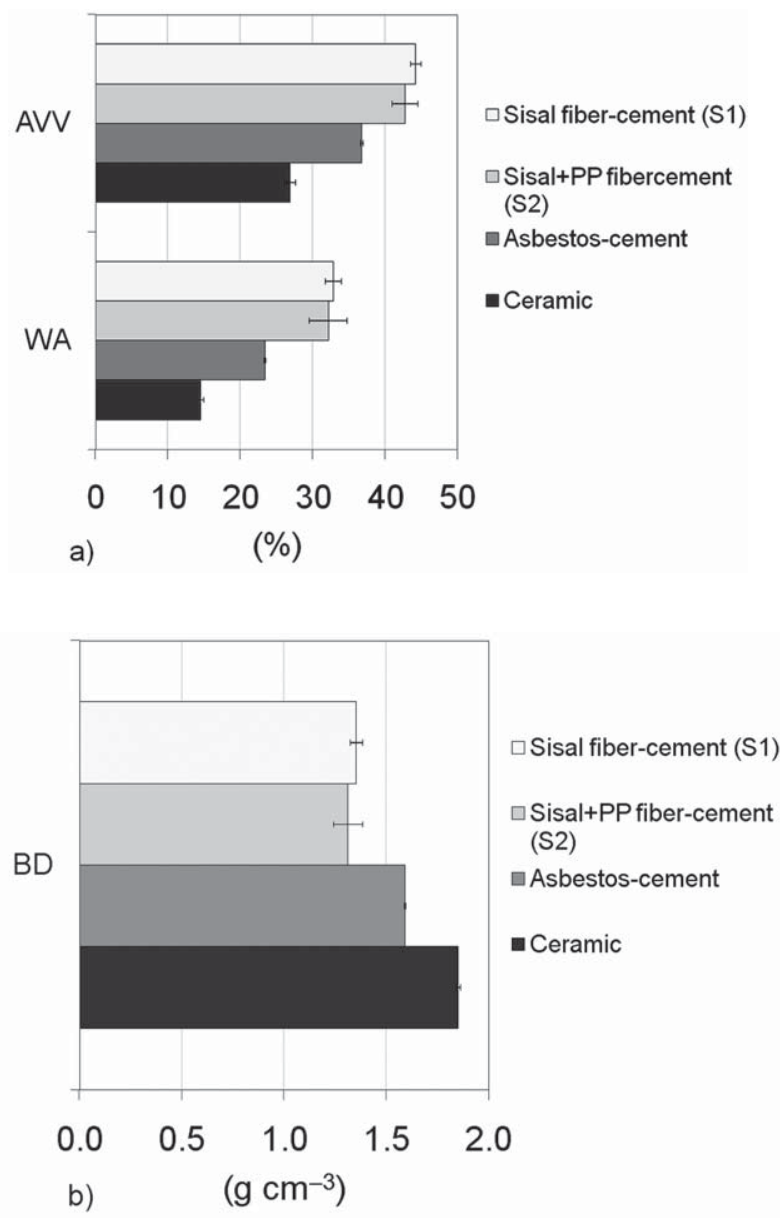

Figure 5 - Mean values and standard deviations for some properties of the roofing tiles: (a) water absorption (WA) and apparent void volume (AVV), (b) bulk density (BD). posites presented different thermal behavior at each temperature. At room temperature $\left(25^{\circ} \mathrm{C}\right)$, the $\mathrm{S} 1$ formulation presented proper thermal properties as far as thermal comfort is concerned, i.e., lower thermal conductivity $k$ and higher specific heat capacity $c$, leading to the lowest thermal diffusivity $\alpha$. Moreover, thermal properties of the mix-design with asbestos at such temperature were less advantageous if compared to the non-asbestos formulations, which can be explained by the presence of sisal pulp and PP fibers. These components tend to trap air into the tile microstructure, thus decreasing the bulk density (Figure 5b) and improving the thermal performance in comparison to asbestos-cement.

At $60^{\circ} \mathrm{C}$, the $\mathrm{S} 2$ formulation was the one presenting adequate values for thermal conductivity and diffusivity. At such temperature, the $\mathrm{S} 1$ formulation presented $k$ and a values $48 \%$ and $68 \%$ higher (respectively) than those for the S2 formulation and 25\% and 50\% higher (respectively) when compared to the asbestos-cement counterparts. The presence of moisture within the prismatic specimens may have influenced the measurements by increasing the thermal conductivity in view of the test temperature rise (Novikov et al., 1973). The higher con-

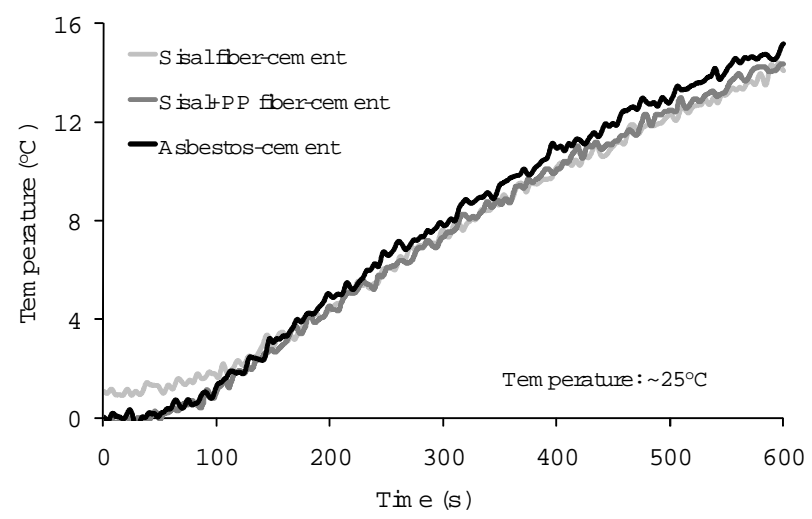

Figure 6 - Temperature-time profile obtained via parallel hotwire method for fiber-cement prismatic specimens at room temperature $\left(\sim 25^{\circ} \mathrm{C}\right)$.

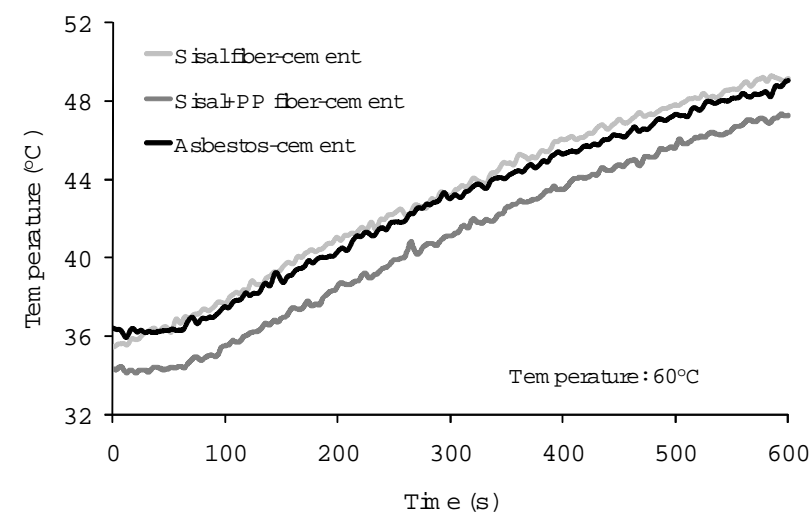

Figure 7 - Temperature-time profile obtained via parallel hotwire method for fiber-cement prismatic specimens at $60^{\circ} \mathrm{C}$. 
tent of cellulose fibers in the S1 formulation allowed corresponding specimens to absorb more water, thus increasing their thermal conductivity at the higher temperature $\left(60^{\circ} \mathrm{C}\right)$.

Data from downside surface temperatures for distinct roofing elements were recorded on days with intense solar radiation. Thermal amplitude was as high as $14^{\circ} \mathrm{C}$ in the period. During the hottest hours of the day, the downside surface temperatures of ceramics roofing tiles were almost $10^{\circ} \mathrm{C}$ and $6^{\circ} \mathrm{C}$ lower than those referring to asbestos-cement and S1 and S2, respectively. The downside surface temperatures of S1 and S2 were almost $3^{\circ} \mathrm{C}$ lower than those of asbestos-cement sheets.
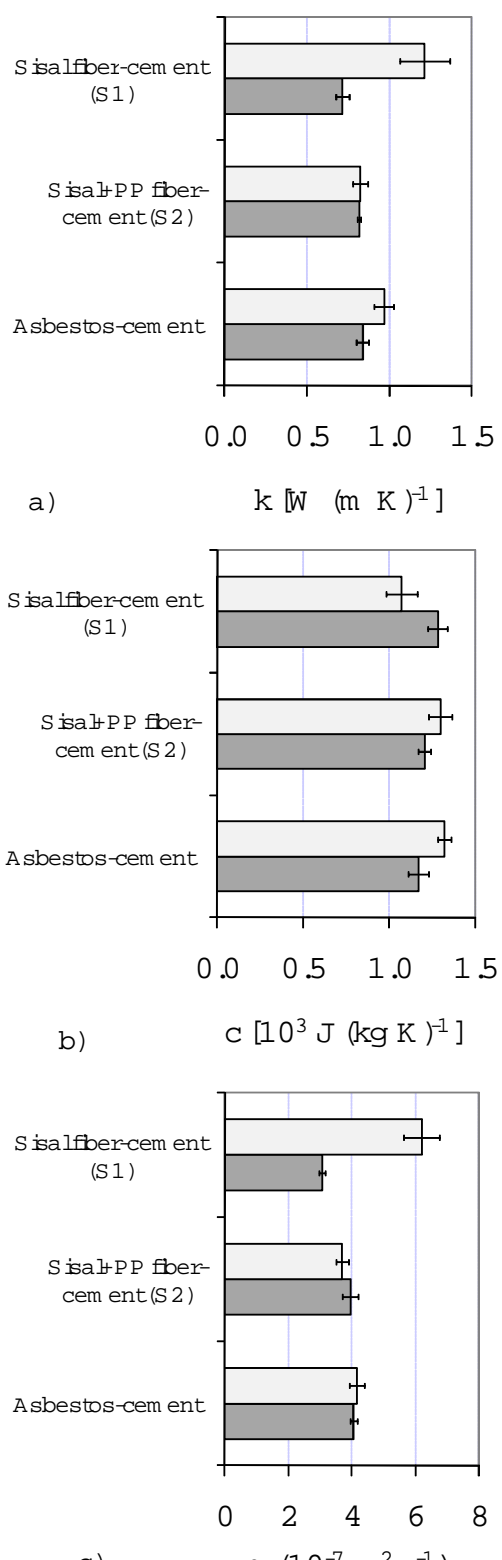

c) $\quad \alpha\left(10^{-7} \mathrm{~m}^{2} \mathrm{~s}^{-1}\right)$

Figure 8 - Average values and standard deviations for (a) thermal conductivity $k$, (b) specific heat capacity $c$ and (c) thermal diffusivity $\alpha$, obtained for the composites via parallel hot-wire method at $25^{\circ} \mathrm{C}$ (dark grey) and at $60^{\circ} \mathrm{C}$ (light grey).
The thermal resistance of the tiles is directly related to its thickness and to the material microstructure. Thickness of ceramic tiles, non-asbestos tiles (S1 and S2) and asbestos-cement sheets were measured as around 12 $\mathrm{mm}, 8 \mathrm{~mm}$ and $4 \mathrm{~mm}$, respectively. The heat transfer rate $\mathrm{d} Q / \mathrm{d} t$ through fiber-cement was assessed using the thermal conductivity at $25^{\circ} \mathrm{C}$ (Figure 8) while the thermal conductivity of the ceramic tiles was adopted as 0.93 W $(\mathrm{m} \mathrm{K})^{-1}$ (Padilha et al., 2001). Figure 9 shows how the incident solar radiation and each heat transfer rate varied over the daylight period under consideration. Heat transfer rates through asbestos-cement sheets were higher (up to $300 \%$ in the hottest hours of the day) than those observed for both ceramic and non-asbestos fiber-cement tiles, which may thus lead to hotter indoor environment in view of the rapid thermal response at the downside surface of the tile.

Thermal inertia is an important characteristic for roofing tiles as it may reduce the amplitude of thermal variation inside the building. As far as thermal inertia analysis is considered, one may divide results into two periods, namely: morning and afternoon. The highest radiation peak (approximately $1,100 \mathrm{~W} \mathrm{~m}^{-2}$ ) occurred around 9 h30 (Figure 9). Its associated thermal effect was observed $1.5 \mathrm{~h}$ later as an increase in the heat transfer rate through tiles. Such phenomenon is attributed to the thermal inertia of the tiles, with the corresponding influence over indoor conditions. In the afternoon, the highest radiation peak happened at $13 \mathrm{~h} 00$ while the maximum heat transfer rate through the asbestos-cement sheets took place at 14h:00. On the other hand, the maximum heat transfer rates were observed at $14 \mathrm{~h} 15$ and $14 \mathrm{~h} 30$ for S1 and S2, and ceramic tiles, respectively, and one may assign these delays to thermal inertia. Regarding the protection against incident solar radiation, both ceramic and fiber-cement tiles (S1 and S2) have better performance than the asbestos-cement sheets.

One may rely on S1 and S2 tiles as means to damp peaks in indoor temperatures in view of the corresponding lower heat transfer rates. Taking into account the reduction of thermal radiation input, the non-asbestos tiles are more efficient than asbestos-cement sheets,

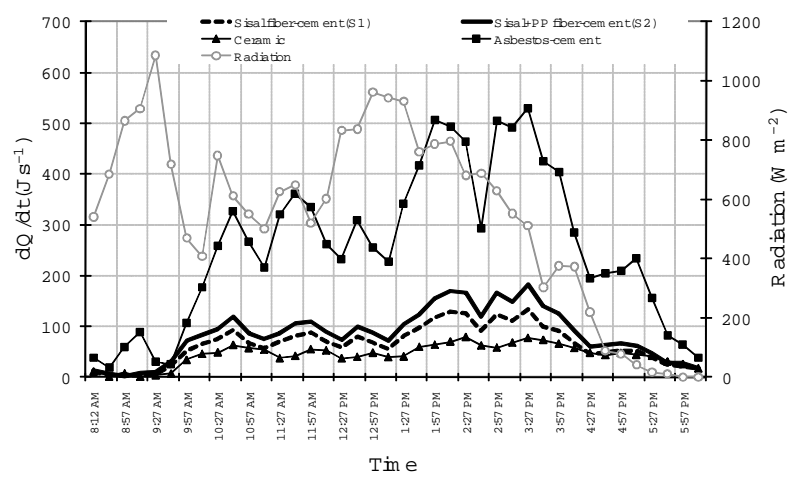

Figure 9 - Incident solar radiation and heat transfer rates $(\mathrm{dQ} /$ $\mathrm{d} t$ ) across roofing tiles and corrugated sheets as a function of time (during daylight period). 
which is in accordance with prior studies. Roma Jr. et al. (2008) found temperature differences of almost $11.5^{\circ} \mathrm{C}$ lower (at 12h00) for fiber-cement roofing tiles reinforced with sisal pulp (produced by vibration) in relation to asbestos-cement corrugated sheets. Kawabata et al. (2005) also found differences in terms of animal thermal comfort as non-asbestos fiber-cement roofing tiles presented better performance than commercial asbestos-cement roofing sheets. Studying fiber-cement roofing components based on blast furnace slag reinforced with eucalyptus pulp, Devito et al. (2003) found temperature gradients of $7^{\circ} \mathrm{C}$ between internal and external surfaces of these tiles.

$\mathrm{S} 1$ and S2 tiles presented lower BD than asbestos-cement and ceramic tiles (Figure 5b). Nevertheless, ceramic tiles presented slightly lower heat transfer rates (Figure 9) in relation to both S1 and S2 tiles, which might be due to their higher infrared reflectance (IR) as shown by Prado and Ferreira (2005) and Roma Jr. et al. (2008). Despite of their dark red surface suggesting a higher absorption $(66 \%)$ in the visible spectrum, the infrared reflectance of ceramic tiles is high enough $(78 \%)$ to render a total reflectance of approximately $67 \%$. The opposite was observed for fiber-cement tiles, with a total reflectance of approximately 40\% (Prado and Ferreira, 2005).

\section{Conclusion}

The mix-design with asbestos is less appropriate if compared to non-asbestos tile formulations at room temperature $\left(\sim 25^{\circ} \mathrm{C}\right)$. Either with or without the further addition of polypropylene (PP) fibers, specimens reinforced with vegetable fibers were more suitable in terms of thermal comfort as they presented lower thermal conductivity and higher specific heat capacity, thus rendering lower thermal diffusivity. Heat transfer rates through asbestos-cement sheets were higher than those across non-asbestos or ceramic tiles. Sisal fiber-cement and sisal + PP fiber-cement tiles presented a thermal performance comparable to that of ceramic tiles, in view of an attractive ability to damp temperature peaks. Lower heat transfer rates and higher thermal inertia observed for non-asbestos fiber-cement tiles may point to higher thermal efficiency, thus rendering them advantages concerning the attenuation of the incident solar radiation.

\section{Acknowledgements}

Financial support for this research project was provided by Brazilian agencies Finep, CNPq, Capes and Fapesp. Cementitious raw-materials were kindly provided by Infibra Ltda., Leme, state of São Paulo, Brazil.

\section{References}

American Society for Testing and Materials [ASTM]. 1981. C 94881: Test Method for Dry and Wet Bulk Density, Water Absorption, and Apparent Porosity of Thin Sections of GlassFiber Reinforced Concrete. ASTM International, West Conshohocken, PA, USA.
Brazilian Technical Standards Association [ABNT]. 1983. NBR 5733: Portland Cement of High Initial Stregth, Specification. ABNT, São Paulo, SP, Brazil. (In Portuguese).

Boregowda, S.C.; Tiwari, S.N.; Chaturvedi, S.K. 2001. Entropy generation method to quantify thermal comfort. Human Performance in Extreme Environments 6: 40-45.

Conceição, M.N.; Alves, S.P.; Telatin Jr., A.; Silva, I.J.O.; Piedade, S.M.S.; Savastano Jr., H.; Tonoli, G. 2008. Performance of tiles composed of blast furnace slag and vegetable fiber in prototype barns. Revista Brasileira de Engenharia Agrícola e Ambiental 12: 536-539. (in Portuguese, with abstract in English).

Devito, R.A.; Vecchia, F.; Silva, A.C. 2003. Eco Technologies: Thermal performance of tiles based on blast furnace slag and reinforced with residual cellulosic fibres. p. 313-322. In: Wendland, E.; Schalch, V., eds. Enviromental research: support for public policy management. RiMA, São Carlos, SP, Brazil. v.2. (in Portuguese).

Grant, R.J.; Albright, J.L. 1995. Feeding behavior and management factors during the transition period in dairy cattle. Journal of Animal Science 73: 2791-803.

International Organization for Standardization [ISO]. 1990. 8894 2: Refractory Materials: Determination of Thermal Conductivity. Part 2. Hot-Wire Method: (Parallel). ISO, Geneva, Switzerland.

Kawabata, C.Y.; Castro, R.C.; Savastano Jr, H. 2005. Thermal comfort indexes and physiological responses of holstein calves in individual houses with different roofings. Engenharia Agrícola 25: 598-607. (in Portuguese, with abstract in English).

Novikov, P.A.; Mikhnyuk, B.G. Subach, V.M. 1973. Thermal conductivity of porous materials in relation to the aggregate state of the filler. Journal of Engineering Physics and Thermophysics 24: 713-716.

Padilha, J.A.S; Toledo Filho, R.D.; Lima, P.R.L.; Joseph, K.; Leal, A.F. 2001. Lightweight sisal pulp-mortar composite: material of low thermal conductivity for rural constructions use. Engenharia Agrícola 21: 1-11. (in Portuguese, with abstract in English).

Prado, R.T.A.; Ferreira, F.L. 2005. Measurement of albedo and analysis of its influence the surface temperature of building roof materials. Energy Buildings 37: 295-300.

Prek, M. 2004. Exergy analysis of thermal comfort. International Journal of Exergy 1: 303-315.

Prek, M. 2006. Thermodynamical analysis of human thermal comfort. Energy 31: 732-743.

Roma Jr. L.C.; Martello, L.S.; Savastano Jr., H. 2008. Evaluation of mechanical, physical and thermal performance of cement-based tiles reinforced with vegetable fibers. Construction and Building Materials 22: 668-674.

Santos, W.N. 2002. The hot wire method: the hot wire parallel technique and the hot wire surface technique. Cerâmica 48: 8691. (in Portuguese, with abstract in English).

Santos, W.N. 2003. Numerical and experimental determination of minimum and maximum measuring times for the hot wire. Cerâmica 49: 29-35. (in Portuguese, with abstract in English).

Santos, W.N. 2008. Advances on the hot wire technique. Journal of the European Ceramic Society 28: 15-20.

Tonoli, G.H.D.; Joaquim, A.P.; Arsène, M.A.; Bilba, K.; Savastano Jr., H. 2007. Performance and durability of cement based composites reinforced with refined sisal pulp. Materials and Manufacturing Processes 22: 149-156.

Tonoli, G.H.D.; Santos, S.F.; Joaquim, A.P.; Savastano Jr, H. 2010. Effect of accelerated carbonation on cementitious roofing tiles reinforced with lignocellulosic fibre. Construction and Building Materials 24: 193-201.

Received August 18, 2009

Accepted May 14, 2010 